\title{
結合水量に基づく自己収縮ひずみと 乾燥収縮ひずみの定量評価
}

\author{
楊 楊 1 佐藤良一 $2 \cdot$ 河合研至 ${ }^{3}$ \\ 1 正会員 工修 広島大学助手 大学院工学研究科（T739-8527 広島県東広島市鏡山1-4-1） \\ 2正会員 工博 広島大学教授 大学院工学研究科（T739-8527 広島県東広島市鏡山1-4-1） \\ 3正会員 工博 広島大学助教授 大学院工学研究科（T739-8527 広島県東広島市鏡山1-4-1）
}

\begin{abstract}
本研究は, 高炉スラグ微粉末を用いた高強度コンクリートを対象とし, セメント系材料の水和進行に基 づいて，自己収縮におよほす乾燥の影響を定量評価することを目的とする.すなわち，セメントの水和進 行の程度を表す尺度として結合水量を用い, その結合水量と自己収縮ひずみとの関係に基づいて, 乾燥下 の自己収縮ひずみを定量評価している，本方法により，乾煤の影響を無視する既往の重ね合わせ法は乾燥 下の自己収縮を過大評価することを指摘するとともに, 乾燥下の自己収縮に及ぼす水結合材比および乾燥 開始材齢の影響と，それらの各条件下における全ひずみに対する自己収縮ひずみと乾燥収縮ひずみの占有 率を示した。
\end{abstract}

Key Words : high strength concrete, blast furnace slag, bound water content, autogenous shrinkage, drying shrinkage

\section{1.はじめに}

従来, コンクリートの体積変化としては, 水和熱 による温度ひずみ及び乾燥収縮ひずみについて検討 するのが一般的であった. しかし，水セメント比が 小さい高強度コンクリート, 高炉スラグ微粉末やシ リカフュームなどの混和材料を用いたコンクリート では, 水和による自己収縮が顕著であるため, ひび 割れ発生に大きく関わることが指摘された ${ }^{1) 。 そ ~}$ の後, 自己収縮に及ぼす水セメント比, 混和材料の 種類と置換率，セメントの種類などの影響が検討さ れた ${ }^{2)}$. 最近では, 自己収縮に関する研究が活発 に行われ，コンクリートの収縮ひずみの予測も試み られている3゙.

これらの研究はほとんど外部との水分のやり取り のない状態のコンクリートを対象とし，あるいは乾 燥を受ける場合においても自己収縮と乾燥収縮は独 立現象として取り扱い，両ひずみ間では重ね合わせ が成り立つと仮定している. しかし，乾燥下の自己 収縮性状はシール状態の性状と異なり, 重ね合わせ が成り立たないとも指摘されている 4)，5，6)。自己 収縮と乾燥収縮との相互関係およびそれらの連成作 用によるひずみの発生機構の検討は緒についたばか
りであり，それらの解明はまだ不十分である．自己 収縮と乾燥収縮との相互関係は，たとえば拘束応力 を求める際の入力データとしてみる場合などでは工 学的意味は薄いが, 微視的アプローチに基づいて予 測する場合，より高精度な予測精度が求められる場 合, セメント硬化体の生成と空隙構造と関係づける 場合などでは, 極めて重要と考えられる.

そこで, 本研究は, 乾燥下の高強度コンクリート の自己収縮と乾燥収縮性状，およびこれらのひずみ の発生機構を明らかにすることを目的とする.すな わち, 高炉スラグ微粉末混入の高強度コンクリート を対象とし, 水結合材比, 乾燥開始材齢をパラメー 夕として, 打込み後から初期乾燥を受けるコンクリ 一トの水和進行を結合水量の観点から定量評価する. 次いで, 水和程度の尺度とする結合水量を自己収縮 ひずみと結びつけ，乾燥下の自己収縮ひずみおよび 乾燥収縮ひずみをそれぞれの分離する．これに基づ き, 乾燥下のコンクリートの自己収縮に及ぼす水結 合材比, 乾燥開始材㱓の影響を検討する. 最後に, 本研究の方法によって評価した自己収縮および乾燥 収縮ひずみと重ね合わせを用いて求めた乾燥下のそ れらとを比較し, 重ね合わせの適用性を検証する. 


\section{2. 既往の研究}

\section{（1）乾焻下の水和進行の評価}

セメントペースト，モルタル及びコンクリートの 全ての物性はセメントの水和進行に依存するため, 水和進行に関する研究は多い. 水和進行の予測に関 する研究も多くの研究者によって行われ, 水和反応 モデルも提案されている ${ }^{7)}$. しかし, それらの研 究の多くは, 水分逸散のない場合に対し, 異なる水 和反応段階の反応速度に着目したものであり, 乾燥 を受ける場合についての研究は少ない。

Bazant ${ }^{8)}$ は細孔内の相対湿度によって水和進行が 異なることを考慮し, 相対湿度と基準となる条件下 での結合水量增加速度を用いて, 式（1）に示す増 分型の乾燥下のコンクリートの結合水量予測式を提 案した ;

$$
d w_{n}=\beta_{T}(h) f\left(w_{n}\right) d t
$$

ここに, $d w_{n}$ : 時間 $d t$ における結合水量増加量

$\beta_{T}(h):$ 相対水和速度（相対湿度 $h$ 之温度 $T$ の関数)

$f\left(w_{n}\right)$ : 基準となる条件（例えば，湿度 $100 \%$ ）での単位時間あたりの結 合水量増加量

式（1）は，乾燥の影響を相対水和速度が低減す ることにより考虑しているが, これ以上水和が進行 しない時点の結合水量，すなわち終局結合水量には 乾燥の影響はないとしている. しかし，乾燥を受け ると, 水和の進行速度が低下するだけでなく, 終局 結合水量も減少することは明らかである，とくに， 水結合材比の小さい高強度コンクリートの場合, 水 和反応に供する水量が元々少なく, さらに水和生成 物の高い縀密性により反応も阻害されるため, 式

（1）は少なくとも高強度コンクリートには適用出 来ない.

永松ら 9) は, 実用性と簡便さを考虑し, 乾燥を 受けない場合の結合水量の経時変化を次式のように 表している.

$$
w_{n}=\frac{W_{n} t}{t+\frac{1}{a_{s} W_{n}}}
$$

ここに, $w_{n}$ : 材齡 $t$ における結合水量

$W_{n}:$ 終局結合水量

$a_{s}:$ 水和の進行しやすさを表わす係数

さらに永松らは上式（2）を乾燥による終局結合
水量の減少を考慮できるように改良した。すすなわち, 乾燥度と終局結合水量低減量との関係を定式化し, これを用いて, 乾燥を受けたモルタルの経時的に変 化する結合水量の予測式を次のように提案した ;

$$
w_{n d}=w_{n k}+\frac{\Delta W_{n d}(t-k)}{(t-k)+\frac{1}{a_{s} \Delta W_{n d}}}
$$

ここに, $w_{n d}$ : 乾燥下の材跉 $t$ における結合水量 $\Delta W_{n d}:$ 乾燥開始材齡 $k$ から終局までの 乾燥下の結合水量の増加量

$$
\Delta W_{n d}=W_{n d}-w_{n k}
$$

$W_{n d}$ : 乾燥下の終局結合水量

$w_{n k}$ : 乾燥開始材齢 $k$ における結合水量,

式（2）より求める

上式の場合，終局結合水量に及ぼす乾燥の影響は 考慮されている．しかし，水和の進行しやすさを表 わす係数 $a_{s}$ は, W/C 毎に定められているが, 乾燥 状態であってもシールした場合と同じ値を用い, 乾 燥の影響を考慮したものとはなっていない.

\section{（2）乾爆下の自己収縮}

JCI 自己収縮研究員会は, 自己収縮には物質の浸 入や逸散, 温度変化, 外力や外部拘束に起因する体 積変化は含まないと定義している ${ }^{10)}$ 。しかし, 自 己収縮はセメントの水和による現象であるため, 水 和進行に影響を及ぼすものであれば，自己収縮にも 影響すると考えられる. 通常, コンクリート構造物 では外部と水のやり取りが行われ，乾燥により水和 反応が阻害される場合が多い．このような水和に及 ぼす乾燥の影響を考えると，特に，初期乾燥を受け る場合, シール状態での自己収縮と乾燥下の自己収 縮は異なることが予想される.

乾燥を受けるコンクリートの自己収縮（以下乾燥 下の自己収縮という），あるいは自己収縮に及ぼす 乾燥の影響に関する研究報告はあるが, 少ないのが 現状である。これらのほとんどは，自己収縮に及ぼ す乾燥の影響を無視し, 自己収縮ひずみと乾燥収縮 ひずみの重ね合わせが成り立つものと仮定して, 乾 燥下の全収縮ひずみから自己収縮ひずみを差し引く ことにより, 乾燥収縮ひずみが便宜的に求められて (いる ${ }^{11)}$ ，12)。このように求めた乾燥収縮ひずみは, 材路の経過と共に一旦増加するがその後減少すると いった普通あり得ない現象を示す場合もある ${ }^{6)}$ 。 一方, 石田ら ${ }^{4)}$ はセメント硬化体の微細機構に基 づいて乾燥収縮・自己収縮による体積変化現象を統 
一的に取扱うことにより，任意の環境，使用材料， 配合及び養生条件下のコンクリートの自己収縮及び 全収縮を数值解析的に評価した.この結果より水和 の進行と同時に乾燥を受ける場合の収縮挙動を適切 に予測するためには, 水分逸散と水和反応両者の相 互作用の考慮が必要と指摘している．筆者ら ${ }^{5)}$ は シリカフューム混入の高強度コンクリートを対象と し, 乾燥による水和反応の抑制を実測結合水量より 評価し，重ね合わせを前提とすれば，乾嬠下の自己 収縮を過大に，乾燥収縮を過小に評価することを示 した.

\section{3. 乾燥下の自己収縮ひずみの評価方法}

\section{（1）結合水量による水和進行の評価}

本研究では, 水和進行の評価は基本的には永松ら と同様の方法によるものとした．乾燥の影響を受け ない, いわゆるシール状態の結合水量の経時変化は 式（2）を用いて評価した.

セメント硬化体の内部構造は水和の進行につれて 緻密になるため, 水和生成物層を通過する水分及び イオンの移動に対する抵抗が大きくなる.すなおち, 末水和セメント粒子と水の反応が阻害されやすく, そのため水和進行も低下すると考えられる.これを 考慮すると, 特に高強度コンクリートの場合, 内部 構造の形成は速くかつ含水量も少ないため, 比較的 若い材齢では, 乾燥開始時期の違いによって水和反 応の進行速度が異なると考えられる．従って，終局 結合水量のみならず結合水量の増加速度にも乾燥開 始材㱓の影響を取り入れるのが妥当と考えられる. これに基づき, 本研究においては, 乾燥下の結合水 量の経時変化を評価する際に, 水和の進行しやすさ を表わす係数 $a_{s}$ をW/C だけではなく，乾燥開始材 齢の影響も考慮して検討することとした.

つまり，式（3）の水和の進行しやすさを表わす 係数 $a_{s}$ を, W/C に加えて乾燥開始材齢の影響を考 慮するという意味で, $a_{d}$ に変え, 式（3）を本研究 の乾燥下の水和進行の評価式とした. なお, 永松ら は係数 $a_{s}$ を水和の進行しやすさを表わす係数と定 義したが，ここでは反応速度に関わる係数と呼ぶ.

シール状態及び乾燥開始材歯の異なる乾燥状態の 結合水量は式（2）および式（3）（この場合 $a_{s}$ は $a_{d}$ に置き換えられている）に示されているように, $W_{n}, \Delta W_{n d}, a_{s}$ および $a_{d}$ がわかれば求められる. 本研究では実測した $w_{n}, w_{n d}$ より最小二乗法を用 いてこれらの值を決定した.

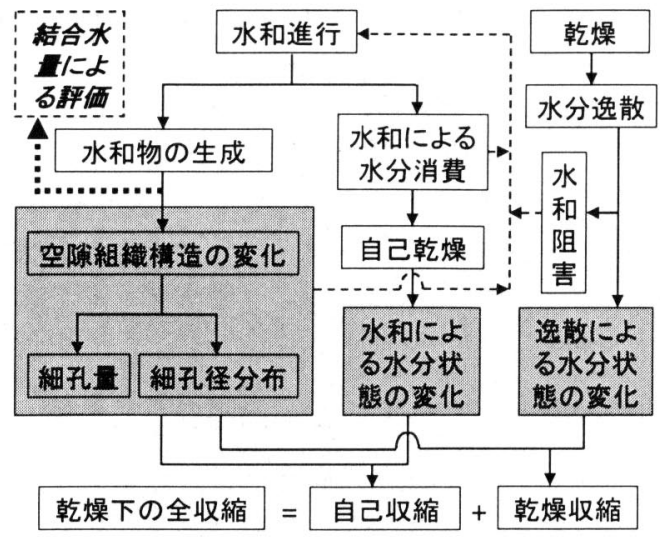

图-1 自己収縮における結合水量の位置づけ

\section{（2）乾燥下の自己収縮ひずみの評価}

コンクリートの自己収縮は, それが乾燥下であっ ても, 細孔径分布とその容積などの空隙構造および その水分状態に影響される 13，14，15)。 。㞒己 収縮は水和進行に伴う空隙中の負圧により生じるた め, 水和進行の尺度である結合水量と密接な関係に あると考えられる. コンクリートが乾燥に曝されれ ば水和反応に供するセメント粒子周辺の水量が減少 するため水和進行が阻害される．このため，乾燥の 影響による収縮が生じるとともに, 結合水量の增加 速度も低下すると考えられる. したがって, 経時的 に変化する結合水量は, 自己収縮の駆動力となる空 隙構造とその含水状態の経時的変化と深い関わりが あると考えられる. 図-1 は, 結合水量と自己収縮 の関係を空隙構造およびその水分状態と関係づけて, また乾燥の影響を考慮して示したものである，図に 示すように結合水量は, 水和進行に伴って生成され た水和物の量を直接表すものであるが, 水和進行が 自己乾燥あるいは乾燥の影響を受けるため, 結果と しては水分状態の影響も含んだものといえる.

本研究では，これらの考えに基づき，さらに結合 水量は任意材齢において直接に測定が可能であるこ とに着目して, 自己収縮および乾燥下の自己収縮を 定量評価するために，自己収縮ひずみは，乾燥下で あっても, 結合水量により一義的に決定されると仮 定した.この仮定は, 同一の結合水量であれば水和 生成物の量も同じであるため, 養生条件の相違に拘 わらず自己収縮ひずみは同一であるとするものであ る. 乾燥開始材齢が異なれば, 空隙構造が相違し自 己収縮も異なることが考えられる. しかし，最近の 研究 ${ }^{16)}$ により, 本研究とセメントまたは配合の相 違はあるものの, 一度乾燥を受け, 再び水分を供給 した硬化体の細孔径分布は水中養生のそれと同様な 


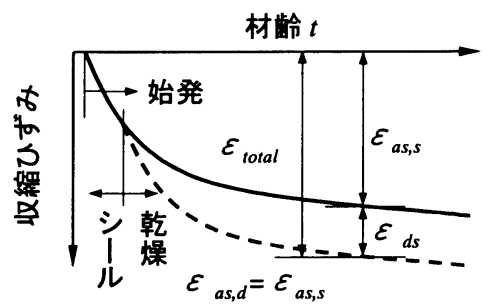

(a) ひずみの重ね合わせ

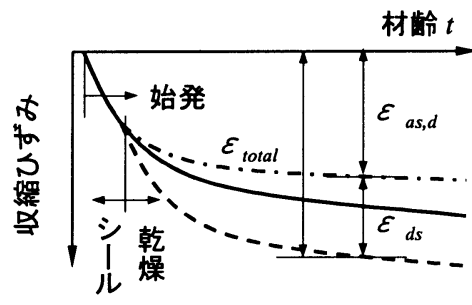

（d）自己収縮と乾燥収縮の分離
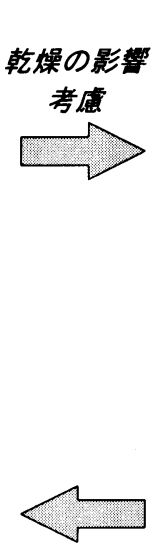

-2乾燥下の自己収縮ひずみの評価手法

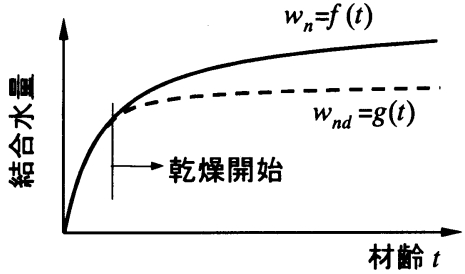

（b）水和反応の定量評価

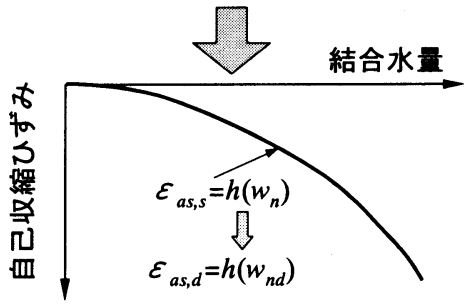

(c) 自己収縮ひずみと

結合水量の関係
形となり, 結合水量すなわち水和率が同じであれば, 総細孔量は等しいことが報告されている.これは上 述の仮定を支持するものと考えられる.

图-2 は乾燥下の自己収縮ひずみと乾燥収縮ひず みの評価方法を, 図-2(a)に示す重ね合わせと図2(b)〜(d)に示す本研究による方法を比較して示し たものである.

乾燥下の自己収縮ひずみ評価の具体的手順を示す と下記のとおりである ;

(1)シール状態下の自己収縮ひずみ $\varepsilon_{a s, s}$, 経時的 変化する結合水量 $w_{n}$ 及び乾燥下の全収縮ひずみ $\varepsilon_{\text {total }}$ ， 結合水量 $w_{n d}$ を測定する.

(2)実測した $w_{n} ， w_{n d}$ に基づいて前述のように, 式（2）および（3）の終局結合水量 $W_{n}, \Delta W_{n d}$ 及 び係数 $a_{s}, a_{d}$ を決定する.

(3)シール状態での自己収縮ひずみ $\varepsilon_{a s, s}$ とシール状 態での結合水量 $w_{n}$ との関係 $\varepsilon_{a s, s}=h\left(w_{n}\right)$ を求める.

(4)シール状態下の $\varepsilon_{a s, s}=h\left(w_{n}\right)$ の関係式を乾燥下 の自己収縮ひずみ $\varepsilon_{a s, d}$ と乾燥下の結合水量の関係 $\varepsilon_{a s, d}=h\left(w_{n d}\right)$ に適用して, 乾燥下の自己収縮ひず みを求める.

(5)図-2(d)に示すように， $\varepsilon_{a s, d}$ を用いて全収縮ひ ずみ $\varepsilon_{\text {total }}$ から $\varepsilon_{a s, d}$ を差し引いて乾燥収縮ひずみ $\varepsilon_{d s}$ を求める.

以上の手順で求めた乾燥下の自己収縮ひずみおよ び乾燥収縮ひずみを用いて，全収縮ひずみに対する 自己収縮及び乾燥収縮の構成を, 異なる水結合材比 W/B および乾燥開始材齢に対して検討する.

\section{4. 実験概要}

（1）使用材料及び配合

本研究では, 普通ポルトランドセメントおよび高 炉スラグ微粉末を結合材として使用した. 実験に使 用した高強度コンクリートの構成材料の諸物性及び 配合をそれぞれ表-1，表-2に示す。

\section{（2）収縮}

自己収縮および乾燥下の収縮実験に用いた供試体 寸法はすべて $100 \times 100 \times 400 \mathrm{~mm}$ とした.

打込み直後からの供試体の変形を拘束しないよう に, JCI 自己収縮研究委員会「セメントペースト, モルタル及びコンクリートの自己収縮及び自己膨張 試験方法（案）」 ${ }^{17)}$ を参照して, 型枠と供試体と の摩摖を極力小さくした. さらに供試体の両端部に 水和熱による熱膨張を拘束しないように厚さ $2 \mathrm{~mm}$ の発泡ポリエチレンシートを設置した. 打ち込み後 の水分逸散を防ぐため, 表面仕上げを行った後, 上 面にラップをしさらにその上に養生マットを被った. 自己収縮供試体は材歯 1 日で脱型し, その直後アル ミ箔粘着テープでシールした，供試体の両端面は, 後述の結合水量を測定した圧縮供試体と同じ体積/ 表面積比になるように, 乾燥開始後もアルミ箔粘着 テープでシールした.

自己収縮ひずみは断面および長さ方向中央部に配 置した埋込型ひずみ計（弾性係数 $40 \mathrm{~N} / \mathrm{mm}^{2}$ ） を用 いて測定した。併せて, 供試体中心の温度を熱電対 
表-2 コンクリートの配合

\begin{tabular}{|c|c|c|c|c|c|c|c|c|c|}
\hline \multirow{2}{*}{ 記号 } & \multirow{2}{*}{$\begin{array}{l}\text { W/B } \\
(\%)\end{array}$} & \multirow{2}{*}{$\begin{array}{c}\text { BS/B } \\
(\%)\end{array}$} & \multirow{2}{*}{$\begin{array}{l}\mathrm{s} / \mathrm{a} \\
(\%)\end{array}$} & \multicolumn{6}{|c|}{ 単位量 $\left(\mathrm{kg} / \mathrm{m}^{3}\right)$} \\
\hline & & & & $\mathrm{W}$ & $\mathrm{C}$ & BS & $S$ & G & $\mathrm{SP}(\times \mathrm{B})$ \\
\hline C-BS25 & 25 & 50 & 41 & 160 & 320 & 320 & 664 & 973 & $0.95 \%$ \\
\hline C-BS35 & 35 & 50 & 45 & 167 & 239 & 239 & 783 & 976 & $1.05 \%$ \\
\hline C-BS45 & 45 & 50 & 47 & 170 & 189 & 189 & 854 & 978 & $1.00 \%$ \\
\hline
\end{tabular}

$\mathrm{B}=\mathrm{C}+\mathrm{BS}$

表-1 使用材料

\begin{tabular}{|c|c|}
\hline 種 類 & 諸物性 \\
\hline $\begin{array}{l}\text { セメント } \\
\mathrm{C}\end{array}$ & $\begin{array}{l}\text { 普通ポルトランドセメント; } \\
\text { 比重: } 3.14 \text {; 比表面積: } 3220 \\
\mathrm{~cm}^{2} / \mathrm{g}\end{array}$ \\
\hline $\begin{array}{l}\text { 高炉スラグ } \\
\text { 微粉末 BS } \\
\end{array}$ & $\begin{array}{l}\text { 比重: } 2.90 \text {; 比表面積: } 6000 \\
\mathrm{~cm}^{2} / \mathrm{g} \text { (Blaine 值) }\end{array}$ \\
\hline $\begin{array}{c}\text { 細骨材 } \\
\text { S }\end{array}$ & $\begin{array}{l}\text { 鬼怒川産川砂（安山岩） } \\
\text { F.M.: 2.93; 比重: } 2.58\end{array}$ \\
\hline $\begin{array}{c}\text { 粗骨材 } \\
\text { G }\end{array}$ & $\begin{array}{l}\text { 鬼怒川産砂利（安山岩） } \\
\text { F.M.: 6.75; 比重: } 2.63\end{array}$ \\
\hline $\begin{array}{c}\text { 高性能減水剂 } \\
\text { SP } \\
\end{array}$ & $\begin{array}{l}\text { ポリカルボン酸エーテル系 } \\
\text { と架橋ポリマーの複合体 }\end{array}$ \\
\hline
\end{tabular}

で測った．これにより測定したひずみは，シールし た状態では断面内の温度差が $1 \sim 2{ }^{\circ} \mathrm{C}$ と小さいので ほぼ正確な自己収縮ひずみと考えられる，乾燥開始 後では, 断面の内で収縮勾配が生じるが, 断面内で はこれによる内部拘束応力の影響を含んだほぼ一様 なひずみが生じ，埋込型ひずみ計ではこの一様なひ ずみを計測することになる.

自己収縮ひずみの測定基点は凝結の始発時点とし， 水結合材比 $25 \%, 35 \%$ おび $45 \%$ のコンクリート （以下W/B25\%, W/B35\%, W/B45\%）の場合, そ れぞれ 0.38 日， 0.43 および 0.56 日であった。

乾燥下の収縮供試体は, 乾燥開始前までは自己収 縮供試体と同様に取り扱い, 乾燥開始時にシールを 外してひずみの経時変化を計測した。乾燥開始材齢 は 1，3，7日とした.

環境温度は $20 \pm 1{ }^{\circ} \mathrm{C}$, 湿度は $60 \pm 5 \%$ でった。 ひずみは全て 2 体の供試体の平均值であるが， 2 体 のひずみ差が大きいものはなかった.

\section{（3）結合水量}

結合水量の測定はセメントペーストを用いて行う のが一般的であるが, 本研究では, 水和進行の評価 に基づいて，乾燥下のコンクリートの自己収縮およ び乾燥収縮の把握を目的としていること, およびペ ーストにおよぼす乾燥の影響はコンクリートの場合 と異なることを考慮して，コンクリート圧縮試験用 供試体から破砕したものを結合水量測定用試料とし

\begin{tabular}{|c|r|}
\multicolumn{1}{c|}{ 表-3 結合水量測定材齢 } \\
\hline $\begin{array}{c}\text { 乾燥材齢 } \\
\text { (日) }\end{array}$ & 結合水量測定材齢（日） \\
\hline シール & $0.5,0.625,0.75,1,1.5,3,5,7,10,14,28,60,90$ \\
\hline 1 & $1,1.5,3,5,7,10,14,28,60,90$ \\
\hline 3 & $3,5,7,10,14,28,60,90$ \\
\hline 7 & $7,10,14,28,60,90$ \\
\hline
\end{tabular}

て用いた．コンクリート压縮試験用供試体の寸法は $\phi 100 \times 200 \mathrm{~mm}$ であり，先述した収縮供試体と同一 体積/表面積比になるように, 乾燥開始後もアルミ 箔粘着テープでシールした.この供試体の圧縮試験 直後に, 供試体の高さ方向上下約 $50 \mathrm{~mm}$ を除く部分 をハンマー等で破砕したものを混合し，大きさ 2.5 〜 5mmのものを試料とした. したがって, ここで得 られた試料は横断面内の平均的な值を与えるもので ある. 試料の質量は $30 \mathrm{~g}$ 程度で, 質量を測定した直 後, アセトンに繰り返し浸漬して水和を停止させた. その試料を 12 時間 $105^{\circ} \mathrm{C}$ 炉乾燥した後, 電気炉内に おいて $600^{\circ} \mathrm{C} て ゙ 4$ 時間加熱した．結合水量は，単位質 量の結合材に結合される水量とし, 式（4）を用い て求めた. 結合材の質量は塩酸により骨材とセメン 卜硬化体を分離して求めた. なお, 結合水量は2体 の供試体から求め, その平均値を用いることとした.

結合水量は表-3に示す所定の材龄において測定し た. この表に示すように, 特に若材齢では水和反応 が早いので短い材齢の間隔で測定した.

$$
w_{n}=\frac{W_{105}-W_{600}}{W_{b}} \times 100 \%
$$

ここに, $w_{n}:$ 結合水量

$W_{105}: 105^{\circ} \mathrm{C}$ 炉乾燥後の試料の質量

$W_{600}: 600^{\circ} \mathrm{C}$ で加熱した試料の質量

$W_{b}:$ 結合材の質量

\section{5. 結果及び考察}

\section{（1）自己収縮及び全収縮ひずみ}

シール状態の自己収縮ひずみの経時変化を図-3 に示す．若材路における高強度コンクリートの熱膨 


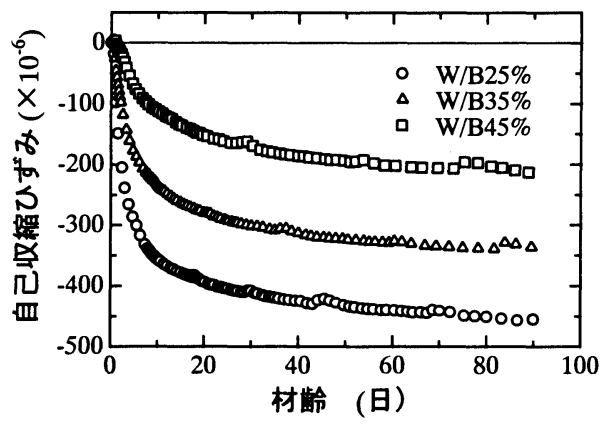

图-3 自己収縮ひずみの経時変化

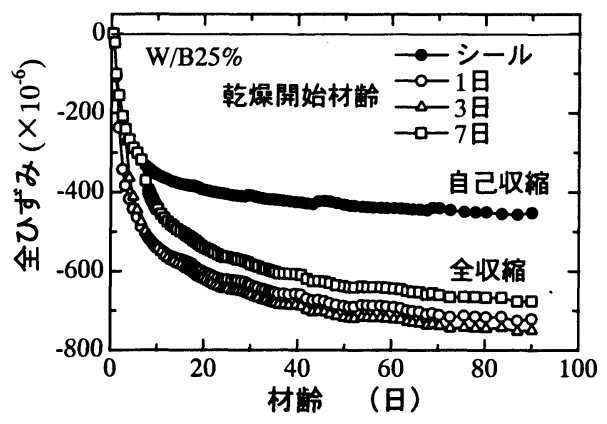

图-5 全収縮ひずみの経時変化

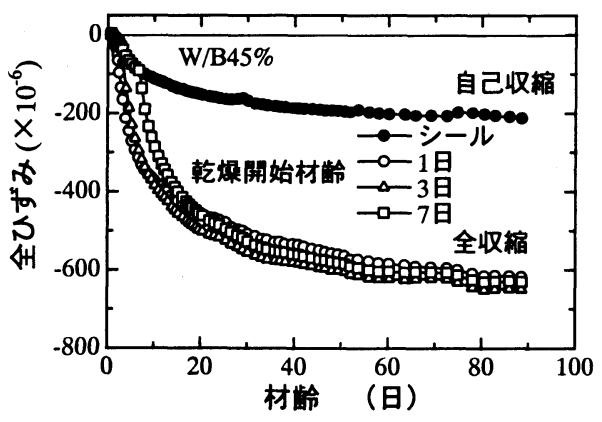

图-7 全収縮ひずみの経時変化

張係数は大きいことが明らかにされつつある ${ }^{18)}$. しかし, $20^{\circ} \mathrm{C}$ 一定下での養生の場合, 凝結の始発時 点からの最大温度上昇量は, W/B25\%の場合 $3.7^{\circ} \mathrm{C}$, $35 \%$ の場合 $2.5^{\circ} \mathrm{C}, 45 \%$ の場合 $1.4^{\circ} \mathrm{C}$ であって, 水和 熱による温度変化が小さく, 熱膨張係数の違いによ る温度ひずみの差が小さい．これを考慮して，ここ では線膨張係数を $10 \times 10^{-6} /{ }^{\circ} \mathrm{C}$ の一定值と仮定して, セメントの水和熱による温度ひずみを補正して自己 収縮ひずみを求めた.

图-3 に示すように，自己収縮ひずみは初期材歯 に急速に増加し, その後漸増した. 材齢 60 日以後 自己収縮ひずみは収束していく傾向がみられる，凝

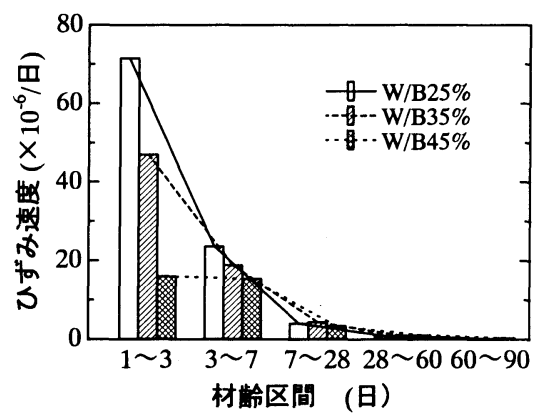

图-4 自己収縮ひずみ速度の比較

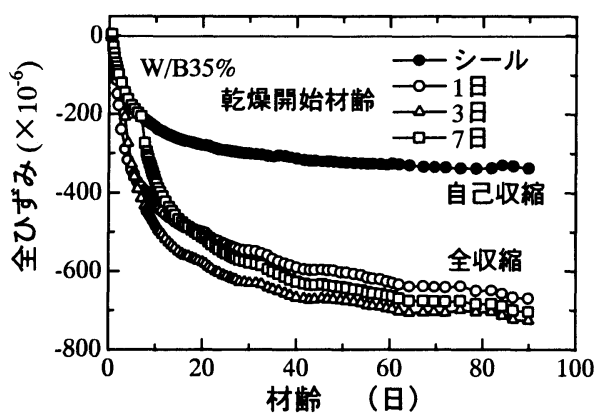

图-6 全収縮ひずみの経時変化

結直後にも自己収縮が生じる W/B25\%の場合と比 べ, $35 \%$ 及び $45 \%$ の場合, わずかの膨張が起こっ ている.これは水和熱による熱膨張の過小評価が原 因と考えられる.

自己収縮は水結合材比が小さいほど進行速度が速 く，ひずみの值も大きい，W/B25\%の場合，材齢 1 日から 3 日にかけて自己収縮ひずみの増加量は 143 $\times 10^{-6}$ で, 3 日から 7 日にかけて $94 \times 10^{-6}$ となる. これに対して，W/B35\%の場合，それぞれ $94 \times 10^{-6}$, $75 \times 10^{-6}$ で，W/B45\%の場合，それぞれ $32 \times 10^{-6}$, $61 \times 10^{-6}$ であった．このひずみ増加量を速度に表わ すと，図-4 のように若材齢において W/B が小さい ほど自己収縮ひずみ速度が速くなる．しかし，材歯 が増すにつれて W/B の違いによるひずみ速度の差 は小さく, 材齢 7 日以降，ほぼ同様な速度になる. 材齢 90 日では, W/B45\%の約 $210 \times 10^{-6}$ の自己収縮 ひずみに対して，W/B35\%の方は $340 \times 10^{-6}$, $\mathrm{W} / \mathrm{B} 25 \%$ の方は $\mathrm{W} / \mathrm{B} 45 \%$ の倍以上 $450 \times 10^{-6}$ のひず みに達している.

乾燥開始材龄の異なる乾燥下のコンクリート全収 縮ひずみを図-5〜図-7に示す，比較のため，同図に シール下の自己収縮ひずみも示している．材齢90日 における全収縮ひずみを乾燥開始材歯の影響を無視 


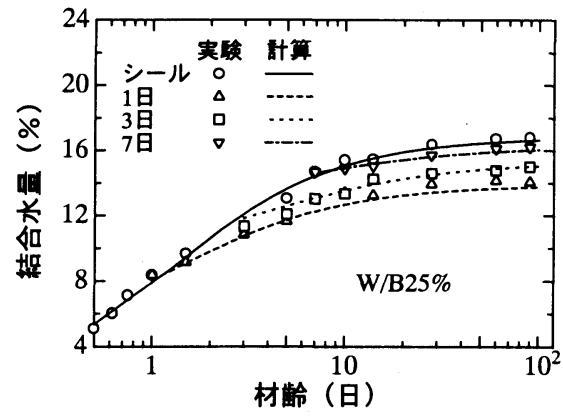

图-8 結合水量の経時変化に及ぼす 乾燥開始材齢の影響（W/B25\%）

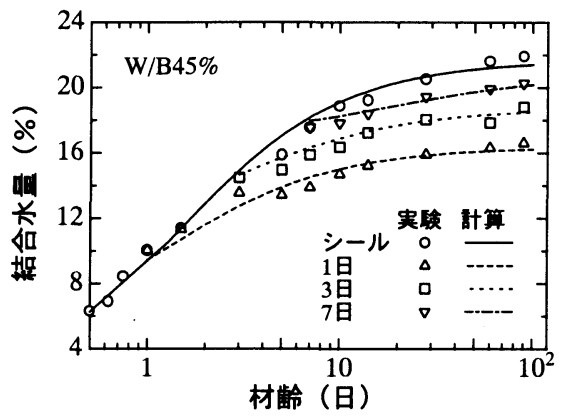

图-10 結合水量の経時変化に及ぼす 乾燥開始材齢の影響（W/B45\%）

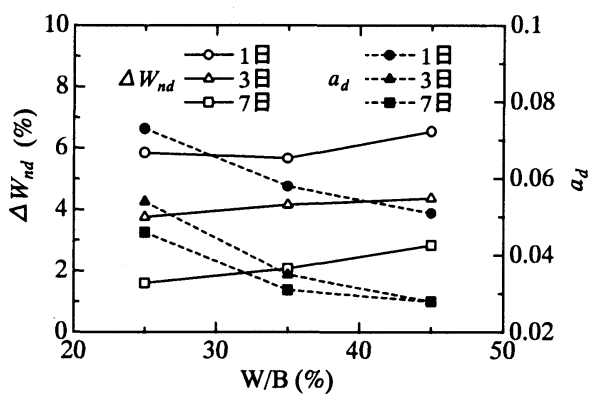

图-12 各乾燥開始材齢における $\Delta W_{n d}$ 及び $a_{d}$ に及ぼす W/B の影響

して平均的にみれば，W/B25\%，W/B35\% および W/B45\%の場合，それぞれ $715 \times 10^{-6}, 700 \times 10^{-6}$ およ び $630 \times 10^{-6}$ となっており，W/Bが小さいほど全収縮 ひずみは大きいことが認められる．これは全収縮ひ ずみが単位水量に依存しないことを示しているとと もに，W/Bが小さいことにより細孔組織が緻密化し ていることが一因と考えられる.

さらに同図によれば，全収縮ひずみと乾燥開始材 歯は必ずしも対応しない。 すなわち，W/B25\%, W/B35\% およびW/B45\%の場合，それぞれ，3，1，

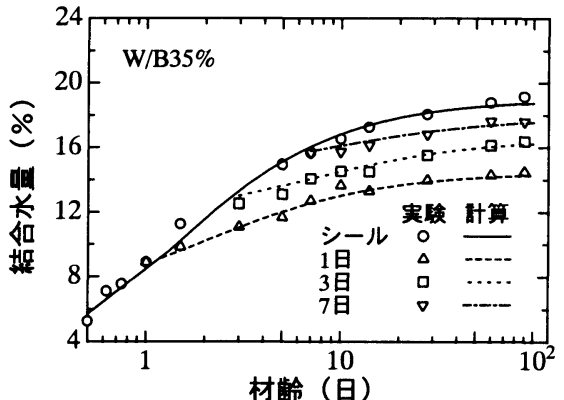

图-9 結合水量の経時変化に及ぼす 乾燥開始材齢の影響（W/B35\%）

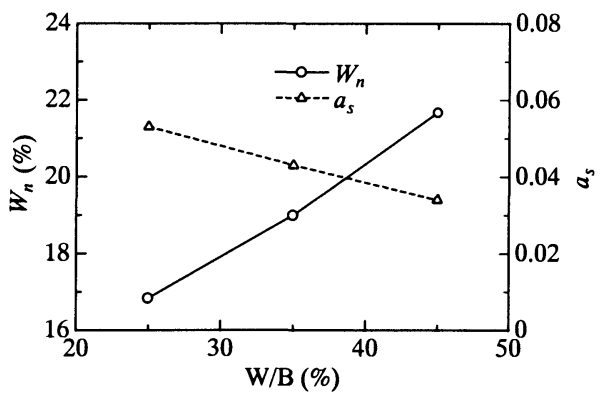

图-11 シール条件下の $W_{n}$ 及び $a_{s}$ に 及ぼす W/Bの影響

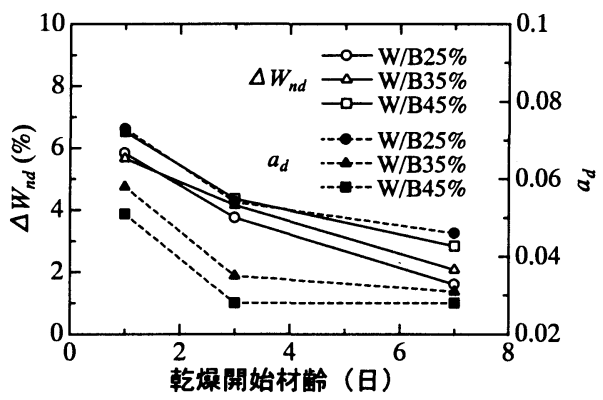

图-13各 W/Bにおける $\Delta W_{n d}$ 及び $a_{d}$ に 及ぼす乾嬠開始材齢の影響

7日，3，7，1日および3，7，1日の乾燥開始材齢の 順に全収縮ひずみは大きく, 必ずしも乾燥開始材齢 が若いことが大きい収縮を発生させることには繋が らない.

\section{（2）乾爆下の高強度コンクリートの水和進行}

図-8〜图-10にW/B25\%，35\%および45\%の，シー ル条件および1，3，7日の各乾燥開始材政毎の実測 結合水量の経時変化を示す. 初期材齢では水和反応 が速いため結合水量が急に増大するが, 材齢ととも に徐々に增加率が低下し, 材歯28日を超えると収束 
关-4 諸定数

\begin{tabular}{|c|c|c|c|c|}
\hline \multirow{2}{*}{ 係数 } & 乾燥開始 & \multicolumn{3}{|c|}{$\mathrm{W} / \mathrm{B}(\%)$} \\
\cline { 3 - 5 } & 材齡(日) & 25 & 35 & 45 \\
\hline$W_{n}$ & シール & 16.83 & 18.99 & 21.68 \\
\hline$a_{s}$ & シール & 0.053 & 0.043 & 0.034 \\
\hline \multirow{4}{*}{$\Delta W_{n d}$} & 1 & 5.84 & 5.66 & 6.53 \\
\cline { 2 - 5 } & 3 & 3.75 & 4.15 & 4.36 \\
\cline { 2 - 5 } & 7 & 1.60 & 2.07 & 2.83 \\
\hline \multirow{3}{*}{$a_{d}$} & 1 & 0.073 & 0.058 & 0.051 \\
\cline { 2 - 5 } & 3 & 0.054 & 0.035 & 0.028 \\
\cline { 2 - 5 } & 7 & 0.046 & 0.031 & 0.028 \\
\hline
\end{tabular}

表-5 材料定数 $a, b$

\begin{tabular}{|c|c|c|c|}
\hline $\mathrm{W} / \mathrm{B}$ & $25 \%$ & $35 \%$ & $45 \%$ \\
\hline$a$ & -1.80 & -1.34 & -0.79 \\
\hline$b$ & 3.66 & 7.91 & 8.21 \\
\hline
\end{tabular}

していく傾向が認められる. W/Bが小さいほどこの 傾向は顕著である.

結合水量は, 若材跉においてはW/Bの違いによる 差は小さいが, 材跉の増加につれてW/Bが小さいほ ど結合水量が小さくなる.いずれのW/Bの場合でも, シ一ル状態と比べ, 乾燥により水和反応が阻害され 乾燥期間の結合水量は小さくなる. 乾燥開始材跉が 若く, W/Bが大きいほどシール状態との結合水量の 差は大きくなる，特にW/B25\%の場合，材歯7日に 開始する乾燥の結合水量に及ぼす影響は小さい。 なみに, シリカフュームを用いたW/B25\%の高強度 コンクリートの場合は, 材齡3日の乾燥開始が結合 水量に及ぼす影響は小さかった5)。これは高炉スラ グ微粉末を多量混入した場合シリカフュームを混入 した場合より水和反応が遅くなるためである.

結合水量の実験データを式（2），（3）にあては めると, シール状態下の終局結合水量 $W_{n}$, 反応速 度に関わる係数 $a_{s}$, 及び乾燥段階における $\Delta W_{n d}$, $a_{d}$ が得られる. それらの結果を図-11, 図-12及び 図-13に示す．終局結合水量は結合材の水和反応が これ以上進まない状態にあたる結合水量である．本 研究では, W/Bの小さい高強度コンクリートを対象 と限定しているため, 材歯 90 日までのデータを用い て回帰より終局結合水量を求めた.

図-11より，外部との水分のやり取りないシール 状態において終局結合水量はW/Bの增大に伴ってほ ぼ直線的に大きくなる。これは, Copeland ${ }^{(9)}$ 及び Asaga $^{20)}$ が指摘したように, 反応率はそれが低い段 階ではW/Bに依存せず一定であるが，その後水和物

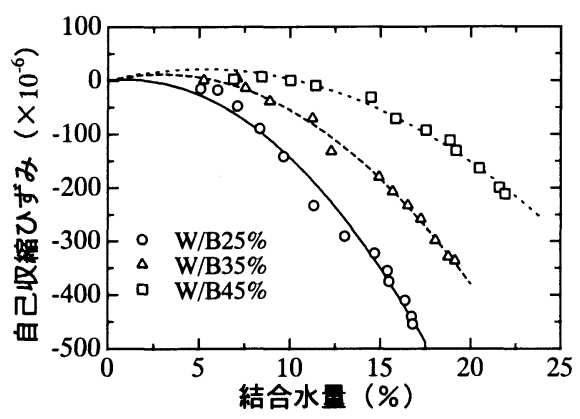

图-14 自己収縮ひずみと結合水量の関係

の生成スペースが少なくなって, W/Bの小さいほど 反応率が低下し, 終局結合水量が小さくなるためと 考えられる. 終局結合水量の低下に応じて, 水和反 応速度に関わる係数は逆にほぼ直線的に大きくなっ た.

シール状態と比べ, 乾燥を受ける場合, 乾燥段階 における終局結合水量の增加量 $\Delta W_{n d}$ に及ぼすW/B の影響は図-12に示すように小さい，一方，乾燥開 始材齢が経過するほど $\Delta W_{n d}$ は小さくなる.これは 遅い時期に乾燥を受ける場合, 水和反応がかなり進 んでいて，反応に供する自由水が少ないためである. 乾燥段階の水和反応速度に関わる係数については,

图-13に示すようにW/Bの增大と乾燥開始材秢の経 過に伴って小さくなる傾向があるが，特に1日から 3 日の間で顕著である.

$W_{n}, a_{s}, \Delta W_{n d}$ および $a_{d}$ をまとめて表-4に示す. これらの值を用い, 式(2)，（3）によって計算した值 を実験值とともに図-8〜图-10に示す，これらから， 少なくとも本研究で用いた高強度コンクリートに対 しては, 結合水量の評価に乾燥開始材跲を考慮する ことの必要性が認められる.

\section{（3）自己収縮ひずみと結合水量の関係}

図-14にシール下の自己収縮ひずみと結合水量の 関係を示す. 図のように, 水和反応の進行を反映す る結合水量の增大とともに自己収縮ひずみが大きく なってくる. しかし, 初期段階においては, 結合水 量の増大しても自己収縮ひずみはほとんど生じない が, 時間の経過とともにその進展は顕著になる.ま た自己収縮発生時の結合水量は W/Bが大きいほど 大きくなる傾向にある. 前者の性状は初期において 大きかった毛細管が水和反応の進展とともに細孔化 し，それにともなって毛細管張力が増大することに よると考えられる. 後者はW/Bが大きいと相対的に 自由水が多く, 細孔構造も緻密性が低下するためで 


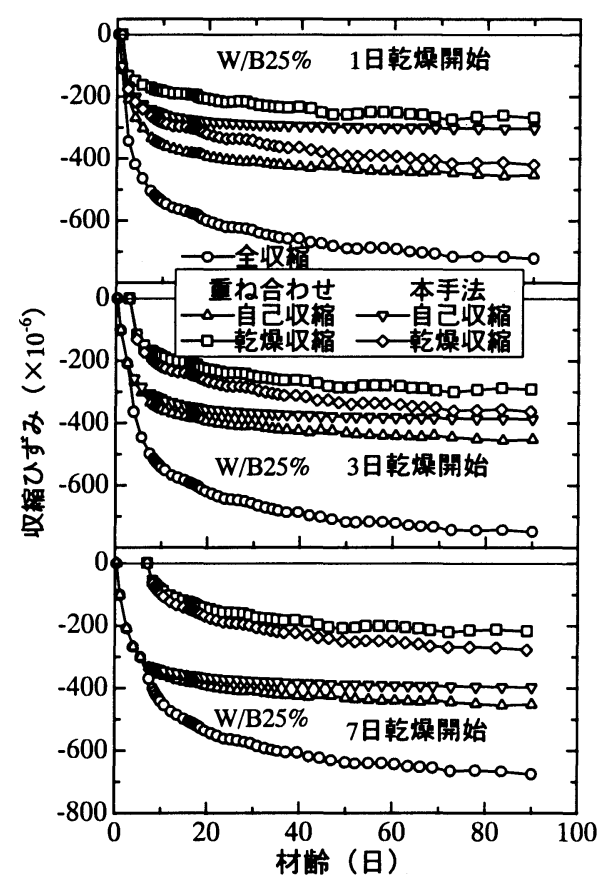

图-15 収縮ひずみ成分（W/B25\%）

ある.

図-14の自己収縮ひずみと結合水量の関係は結合 水量の小さい領域を除けば式 (5)に示す放物線で表 わすことができる.

$$
\varepsilon_{a s, s}=a w_{n}^{2}+b w_{n}
$$

ここに， $a ， b$ は材料定数で, W/Bによって異な る. 回帰によって求めたそれらの值を表-5に示す. 乾燥下の自己収縮ひずみ $\varepsilon_{a s, d}$ も結合水量に一義的 に依存すると仮定しているので式 (5) と同一の式 （6）で求められる.

$$
\varepsilon_{a s, d}=a w_{n d}^{2}+b w_{n d}
$$

\section{ここで, $w_{n d}$ は式(3)から得られる.}

乾燥下の自己収縮ひずみ $\varepsilon_{a s, d}$ は上式で求められ るので, 全収縮ひずみ $\varepsilon_{\text {total }}$ から乾燥下の自己収縮 ひずみを差し引くことにより乾燥収縮ひずみ $\varepsilon_{d s}$ が 次のように求まる.

$$
\varepsilon_{d s}=\varepsilon_{t o t a l}-\varepsilon_{a s, d}
$$

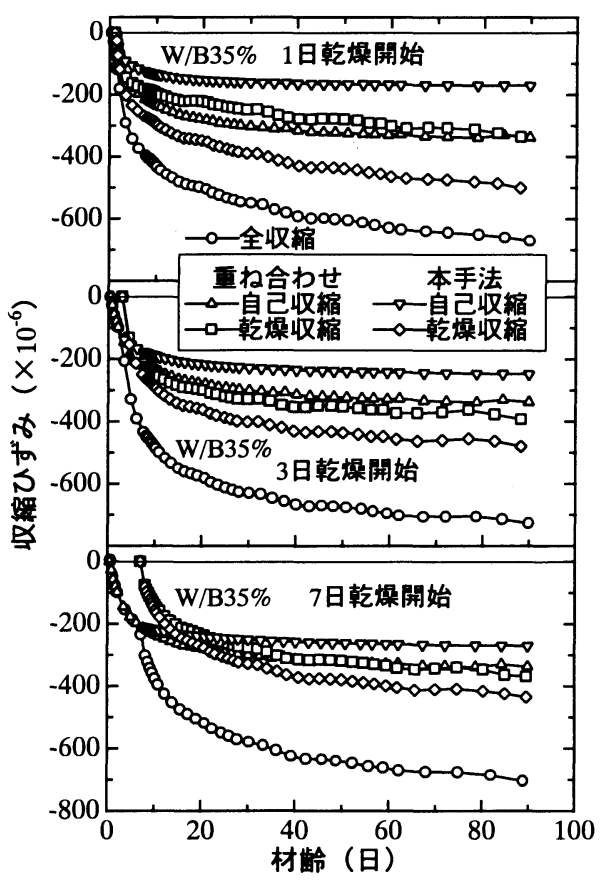

图-16 収縮ひずみ成分（W/B35\%）

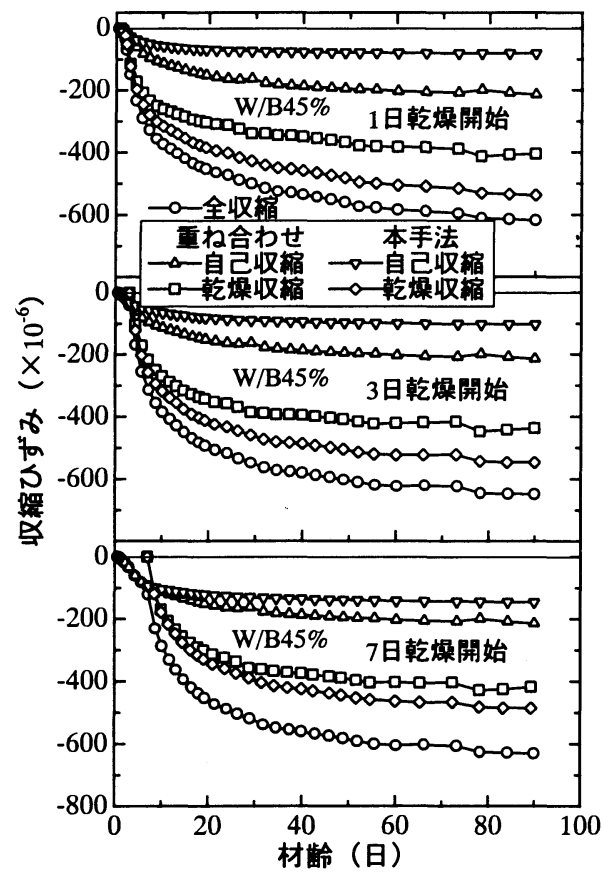

图-17 収縮ひずみ成分（W/B45\%）

（4）収縮ひずみの評価

a）自己収縮ひずみと乾焻収縮ひずみの分離

乾燥下の高強度コンクリートの収縮ひずみ成分を 


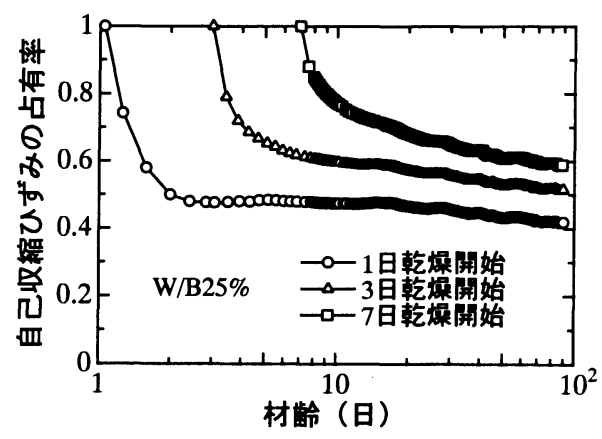

图-18 収縮ひずみの占有率（W/B25\%）

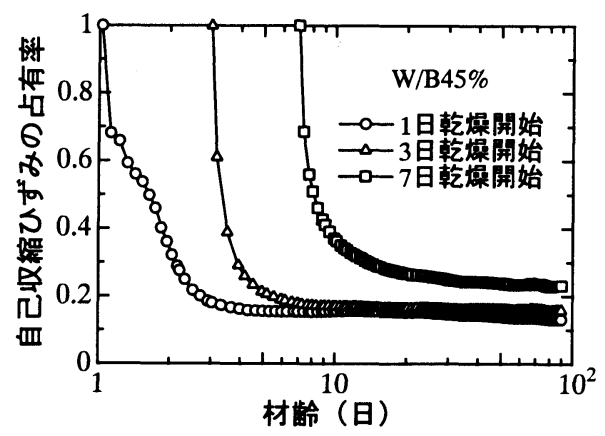

图-20 収縮ひずみの占有率（W/B45\%）

評価するためには，自己収縮ひずみと乾燥収縮ひず みとの分離が不可欠である．乾燥下およびシール状 態下それぞれの自己収縮ひずみが等しいとする重ね 合わせによる方法と, 乾燥の影響による自己収縮の 低減を考慮して乾燥下の自己収縮ひずみを求める本 手法により，両ひずみの分離を行った結果をそれぞ れ比較して图-15〜图-17に示す，図中の○記号が全 収縮ひずみの実測値を表している. 本手法により求 めた乾燥下の自己収縮ひずみと比べ, 重ね合わせに よる乾燥下の自己収縮ひずみは過大評価されること がわかる，そこで，これらの相違を式（8）で定義 する過大評価率 $\alpha$ を用いて検討することとした. こ こで，収縮ひずみは材㱓90日の值を用いた.

$$
\alpha=\frac{\varepsilon_{\text {sup }}-\varepsilon_{\text {pro }}}{\varepsilon_{\text {pro }}} \times 100 \%
$$

ここに， $\varepsilon_{\text {sup }}$ : 重ねあわせによる自己収縮ひずみ $\varepsilon_{\text {pro }}$ : 本手法による自己収縮ひずみ

その結果, W/Bが $25 \%, 35 \%$ および $45 \%$ の過大評 価率は，乾燥開始材齢が1日の場合，約 $49 \% ， 98 \%$ ，

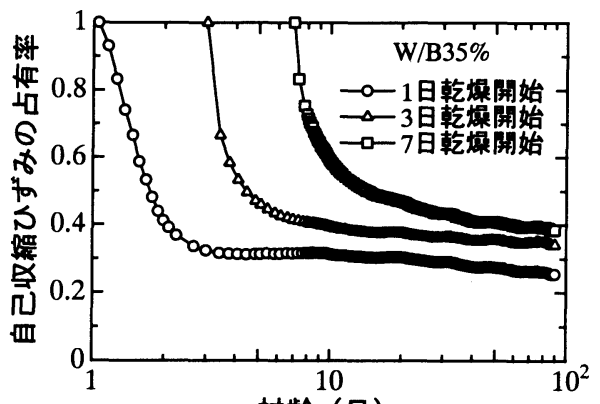

材路（日）

图-19 収縮ひずみの占有率（W/B35\%）

162\%であり，3日の場合，17\%，35\%，106\%で， 7

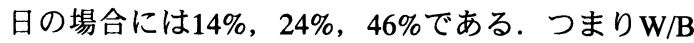
が同一の場合, 乾燥開始材歯が早いほど乾燥の影響 が大きく, 重ね合わせによる自己収縮ひずみを過大 評価する．また評価方法の相違による自己収縮ひず みの差も大きくなる，乾燥開始材齢が同じ場合は, W/Bが大きいほど自己収縮評価におよぼす乾燥の影 響は大きいが, ひずみ差は大きくは異ならない.

一方上述の検討に基づけば，W/B25\%および W/B35\%が乾燥に曝されたとしてもその材齢が3日 以降および7日以降であれば, シール状態の自己収 縮ひずみを乾燥下の自己収縮ひずみとみなしても, その過大評価率は25\%以内であって，それほど大き な差が生じない。

\section{b）自己収縮ひずみの占有率}

水和進行の評価に基づく本研究の手法を用いて実 測全収縮から分離した自己収縮ひずみの全収縮ひず みに対する割合を式（9）で定義する占有率 $\beta$ とし， これにより求めた結果を图-18〜图-20に示す.

$$
\beta=\frac{\varepsilon_{a s, d}}{\varepsilon_{\text {total }}} \times 100 \%
$$

ここに, $\varepsilon_{a s, d}, \varepsilon_{\text {total }}$ は図-2（d）に示すとおりであ る.

いずれの乾燥開始材齢においても乾燥によって自 己収縮の占有率は材齢の経過とともに低減し，W/B が大きい場合この低減は急激になる. 自己収縮ひず みの占有率がほぼ一定となる材齢 90 日における值で 評価すれば，W/Bが占有率に及ぼす影響は大きい。 すなわち, 乾燥開始材跉を無視し巨視的にみれば, W/B25\%, W/B35\% およびW/B45\%の場合の占有率 はそれぞれ約50\%，30\%および20\%である．乾燥開 始が遅くなると当然自己収縮の占有率は大きくなる 
が，乾燥開始材齢の影響はW/Bが小さくなるほど大 きくなる．ちなみに，乾燥開始材跉が1日と7日の場 合の差はW/B25\%，W/B35\% およびW/B45\%の場合 それぞれおよそ20\%，15\%および10\%である.

上記の検討から，本研究に用いた高強度コンクリ 一トの場合には, それが初期から乾燥を受けた場合 であっても, 水結合材比が25\%程度であれば収縮の およそ半分が自己収縮に占められ，順次W/B35\%, $45 \%$ と水結合材比が大きくなると乾燥収縮が支配的 になってくることがわかる.

\section{6. まとめ}

本研究は, 置換率50\%の高炬スラグ微粉末を用い た高強度コンクリートを対象とし，水和進行に基づ いて乾燥下の自己収縮ひずみおよび乾燥収縮ひずみ を定量評価し，それぞれの全収縮ひずみに対する占 有率を明らかにするとともに重ね合わせの適用性に ついて検討を行ったものである. 本研究の範囲で得 られた結果をまとめると以下のとおりである.

(1) 乾燥開始後の結合水量に乾燥開始材齡が影響 し，その影響は，水結合材比（W/B）が25\%〜 45\% の範囲では, 乾燥開始材歯が若いほどまたW/Bが大 きくなるほど顕著である.

（2）水和の進行のし易さを表す係数（本論文では 反応速度に関わる係数）に乾燥開始材歯の影響を取 り込むことにより既往の結合水量予測式を改良し, 実験との比較によりその妥当性を確認した.

（3）シールしたコンクリートの自己収縮ひずみは, 所定の W/B において, 結合水量によりほぼ一義的 に表される. その関係は, 初期の材路令除けば, 放 物線で表すことが出来る. また同一結合水量におけ る自己収縮ひずみは W/B が小さくなると大きくな る.

（4）結合水量を尺度とする水和進行の評価に基づ いて，乾燥下にあるコンクリートの自己収縮ひずみ と乾燥収縮ひずみの分離を行った.

（5）乾燥の影響を無視する重ね合わせに基づいて 得られた自己収縮ひずみは, 乾燥開始材齢が若いほ どまたW/Bが大きいほど過大評価される. しかし, W/Bが25\%および35\%で乾燥開始材齢が3日以降およ び7日以降であれば，その誤差は $25 \%$ 以内であり， シール状態の自己収縮ひずみを乾燥下の自己収縮ひ ずみとおおむねみなせ，実用的に用いることが可能 である.

（6）乾燥下の自己収縮ひずみが全収縮に占める割 合は，乾燥開始材齢を無視し巨視的にみれば， $50 \%$
〜20\%であり, 水結合材比が大きくなると乾燥収縮 が支配的になる. 自己収縮ひずみの占める割合に対 する乾燥開始材齢の影響は, 乾燥開始材齢が1日と7 日を比較した場合，その割合の差は20\%〜10\%であ り, W/Bが小さくなるほど大きくなる.

謝辞 : 本研究の一部はセメント協会研究奖励金の補 助を受け行なわれたものであることを記し感謝の意 を表する.

\section{参考文献}

1) Paillere, A. M., Buil, M. and Serrano, J. J.: Effect of Fiber Addition on the Autogenous Shrinkage of Silica Fume Concrete, ACI Material Journal, V.86, No.2, pp.139-144, 1989.

2）例えば，田澤栄一，宮澤伸吾 : セメント系材料の自 己収縮に及ぼす結合材及び配合の影響, 土木学会論 文集, No.502/V-25, pp.43-52, 1994.

3）田澤栄一, 宮澤伸吾 : コンクリートの自己収縮ひず みの予測法に関する研究, 土木学会論文集, No.571/V-36, pp.211-219, 1997.

4) 石田哲也, R. P. Chaube, 岸利治, 前川宏一: 微細的 機構に基づくコンクリートの自己収縮, 乾嬠収縮及 びその複合に関する解析的検討, 土木学会論文集, No.578/V-37, pp.111-121, 1997.

5）楊 楊, 佐藤良一, 許明: 高強度コンクリートの収 縮及び拘束応力に関する実験的研究, コンクリート工 学年次論文報告集, Vol.20, No.1, pp.631-636, 1998.

6) 阿部哲良, 内藤英晴, 三浦尚 : 自己収縮と乾燥収縮 とを同時に受ける高流動性コンクリートの収縮に関 する研究, セメント・コンクリート論文集, No.52, pp.564-571, 1998.

7) 例えば, 近藤連一, 小玉正雄 : 水和反応速度に関す る考察，セメント技術年報，Vol.21，pp.77-82， 1967.

8) Bazant, Z. P.: Constitutive Equation for Concrete Creep and Shrinkage Based on Thermodynamics of Multiphase Systems, Materiaux et Constructions, Vol.3, No.13, pp.336, 1970.

9) 永松静也, 竹田吉紹, 佐藤嘉昭: 乾燥を受けるセメ ント硬化体の水和の進行を表わす式, 日本建築学会 構造系論文報告集, No.361, pp.21-30, 1986.

10）日本コンクリート工学協会 : 用語の定義, 自己収縮 委員会報告書, pp.1-5, 1996.

11) Tazawa, E. and Miyazawa, S.: Experimental Study on Mechanism of Autogenous Shrinkage of Concrete, Cement and Concrete Research, Vol.25, No.8, pp.1633-1638, 1995.

12) 今本啓一, 大谷博: 高強度・超高強度コンクリート の収縮性状に関する研究, コンクリート工学年次論 
文報告集，Vol.17，No.1，pp.1061-1066, 1995.

13) 平尾宙, 内川浩, 羽原俊祐 : 硬化セメントペースト の湿度及び硬化体構造の変化之自己収縮, コンクリ

一ト工学年次論文報告集, Vol.18, No.1, pp.705-710, 1996.

14) 田中享二, 橋田浩, 端直人 : 若材齢モルタルの乾嬠 途中における細孔構造と水分状態, 日本建築学会構 造系論文集, No.460, pp.11-18, 1994.

15) 羽原俊祐, 沢木大介, 内川浩 : 硬化モルタルの組織, 空隙構造と乾燥収縮との関係（水セメント比と前養 生期間の影製），セメント・コンクリート論文集, No.45, pp.280-285, 1991.

16) 伊代田岳史, 魚本健人 : 乾燥による水和停止後の水 分再供給による水和挙動, 第 55 回セメント技術大会 講演要旨, pp.16-17, 2001.

17) 日本コンクリート工学協会 : 試験方法 - 同解説, 自 己収縮委員会報告書, pp.191-201， 1996.
18）楊 楊, 佐藤良一, 田澤栄一：硬化過程にある高強 度コンクリートの線膨張係数測定方法の一提案, コ ンクリート工学年次論文報告集, Vol.22, No.2, pp.961-966, 2000.

19) Copeland, L. E. and Kantro, D. L.: Hydration of Portland Cement, Proceedings of $5^{\text {th }}$ International Congress, Chemistry of Cement, Tokyo, Japan, Vol. II, pp.387-421, 1968.

20) Asaga, K., Ishizaki, M., Takahashi, S., Konishi, K., Tsurumi, T. and Daimon, M.: Effect of Curing Temperature on the Hydration of Portland Cement Compound, Proceedings of $9^{\text {th }}$ International Congress, Chemistry of Cement, New Delhi, India, Vol.IV, pp.181$187,1992$.

(2001.1.15 受付)

\title{
EVALUATION OF AUTOGENOUS SHRINKAGE AND DRYING SHRINKAGE BASED ON BOUND WATER CONTENT OF CEMENTITIOUS MATERIALS
}

\author{
Yang YANG, Ryoichi SATO and Kenji KAWAI
}

\begin{abstract}
The present study aimed at evaluating autogenous and drying shrinkage of high strength concrete quantitatively. For this purpose, bound water content of concrete sealed as well as exposed to drying at different ages was measured and the relationship between autogenous shrinkage strain and bound water content of sealed concrete was obtained. Assuming that autogenous shrinkage strain depends only on bound water content even under drying, autogenous shrinkage strain under drying was estimated and then drying shrinkage was calculated. The present method showed that the conventional method based on the superposition principle overestimated autogenous shrinkage strain under drying, which also gave the percentages of autogenous shrinkage strain for total strain.
\end{abstract}

